\title{
Moderasi Islam Ahmad Syafii Maarif (Kontribusinya terhadap Pluralitas Agama di Indonesia)
}

\author{
Riki Saputra \\ Universitas Muhammadiyah Sumatera Barat, Padang, Indonesia \\ rikisaputra.rs87@gmail.com
}

\author{
Rido Putra \\ Universitas Islam Negeri Imam Bonjol, Padang, Indonesia \\ ridhosipoetrakampai@gmail.com \\ Endrika Widdia Putri \\ Universitas Islam Negeri Imam Bonjol, Padang, Indonesia \\ putriendrikawiddia@gmail.com
}

\begin{abstract}
This study aims to explain the moderation of Islam in Ahmad Syafii Maarif's view which has contributed to the plurality of religions in Indonesia. This research is library research using descriptive-analytical methods and deductive reasoning. In Ahmad Syafii Maarif's view, Islamic moderation is about providing a reinterpretation of religious texts (Islam) with the aim that adherents can understand religion in essence and substance, which will lead to healthier tolerance among religious communities. To realize the moderation of Islam, Ahmad Syafii Maarif made various efforts including; active in various interfaith forums, voicing messages of moderation through writings, also initiated the establishment of the Maarif Institute, institution engaged in the humanitarian and cultural sector. Meanwhile, Ahmad Syafii Maarif's contribution of Islamic moderation to the plurality of religions in Indonesia is that it has sparked the enthusiasm of young people to hold a dialogue in various interfaith forums.
\end{abstract}

Keywords: Ahmad Syafii Maarif, Islamic moderation, radicalism 


\begin{abstract}
Abstrak
Penelitian ini bertujuan untuk menjelaskan moderasi Islam dalam pandangan Ahmad Syafii Maarif yang memiliki kontribusi terhadap pluralitas agama di Indonesia. Penelitian ini merupakan penelitian kepustakaan dengan menggunakan metode deskriptif-analitis serta penalaran deduktif. Dalam pandangan Ahmad Syafii Maarif, moderasi Islam adalah tentang memberikan tafsir ulang teks agama (Islam) dengan tujuan agar penganutnya dapat memahami agama secara esensi dan substansi, yang mana muaranya akan melahirkan semakin sehatnya sikap toleransi di tengah-tengah umat beragama. Untuk mewujudkan moderasi Islam tersebut Ahmad Syafii Maarif melakukan berbagai upaya di antaranya; aktif di berbagai forum lintas iman, menyuarakan pesan moderasi lewat tulisan-tulisan, juga memprakarsai berdirinya Maarif Institute, lembaga yang bergerak di bidang kemanusiaan dan kebudayaan. Sementara kontribusi moderasi Islam Ahmad Syafii Maarif terhadap pluralitas agama di Indonesia adalah memantik semangat anak-anak muda menyelenggarakan dialog di berbagai forum lintas agama.
\end{abstract}

Kata Kunci: Ahmad Syafii Maarif, moderasi Islam, radikalisme

\title{
Pendahuluan
}

Radikalisme masih menjadi masalah serius bagi banyak kalangan. Paham ini sudah merasuki pemahaman anak-anak muda di Indonesia. Kita lihat misalnya hasil survei Infid, Gusdurian dan NU Online tahun 2017 terhadap 1.200 anak muda usia 15-30 di enam kota (Bandung, Yogyakarta, Surabaya, Pontianak, dan Makassar) berdasarkan data yang penulis temukan pada seminar "Pemuda untuk Indonesia Damai" di UIN Sunan Kalijaga Yogyakarta (Ikhwan, 2018) menyebutkan bahwa intoleransi di kalangan anak muda cukup tinggi, terutama dalam hubungan antar-agama. Hasil survei tersebut diperoleh 49\% responden menolak mengucapkan "Selamat Natal". Sekalipun $88.2 \%$ responden menolak menggunakan kekerasan dalam mempertahankan agama. Melihat angka survei di atas, aktivis pemuda lintas iman harus terus menyuarakan perdamaian serta melakukan kegiatan dialog antar-iman.

Pada 2018, Alvara Research Centre juga merilis hasil surveinya. Lembaga ini menemukan kecenderungan peningkatan trend radikalisme di kalangan pelajar SMU. Hasilnya $23.3 \%$ pelajar mendukung perjuangan negara Islam, dan $21.9 \%$ mendukung implementasi Syariah di Indonesia. Tidak kalah pentingnya akhir-akhir ini PPIM UIN Syarif Hidayatullah juga menunjukkan hasil Survei di 34 provinsi, terdapat 58.5\% pelajar memiliki opini radikal (Ikhwan, 2018).

Data tersebut menunjukkan, bahwa semakin marak geliat gerakan radikalisme agama yang bertebaran di Indonesia (Paath, 2018). Berbagai upaya tentunya sudah dilakukan oleh para tokoh inklusif, maupun para aktivis lintas iman, baik secara teoretis maupun praktis. Begitu pula secara perorangan 
maupun lembaga. Seorang tokoh bangsa yang saat ini menjadi perhatian publik ikut mengecam tindakan radikalisme agama, yakni Ahmad Syafii Maarif, yang lebih populer dipanggil Buya Syafii, Ia merupakan mantan ketua PP Muhammadiyah (1998-2005). Buya Syafii mempunyai peran penting dalam organisasi yang pernah Ia pimpin selama dua periode tersebut karena ketokohannya. Selain karena ketokohannya dalam memimpin salah satu organisasi agama terbesar di Indonesia, Ia juga merupakan aktivis lintas iman dan perdamaian dunia (Qodir, 2015, hal. 368).

Buya Syafii adalah seorang guru bangsa, kontribusinya cukup berarti dalam melakukan upaya moderasi agama di Indonesia dengan berbagai cara. Hal itu dibuktikan dengan ikut merespons berbagai kasus kekerasan agama yang beruntun terjadi pada 2018 lalu. Pasca peristiwa teror terhadap Romo Prier beserta jamaatnya di gereja Lidwina, Buya Syafii mengutuk keras pelaku penyerangan tersebut, sehingga datang berkunjung ke tempat terjadinya teror tersebut. (Hanafi, 2018; Kardi, 2016).

Buya Syafii menyadari ancaman radikalisme dan terorisme bagi keutuhan bangsa yang sanagt berpengaruh terhadap pergolakan arena politik Indonesia pasca tumbangnya rezim Orde Baru. Seiring ledakan konflik komunal berdarah di beberapa kawasan Indonesia, kelompok radikal berbendera Islam, seperti Laskar Pembela Islam, Laskar Jihad, dan Laskar Mujahidin Indonesia, muncul ke permukaan. Mereka aktif berdemonstrasi dengan cara kekerasan (Hasan, 2015, hal. 77).

Berbagai upaya moderasi agama telah dilakukan oleh beberapa lembaga yang bergerak di bidang perdamaian lintas agama. Di antaranya: Interfidei, YIPC, Gusdurian, Srikandi Lintas Iman, dan Maarif Institute. Secara umum, lembaga-lembaga ini telah melakukan upaya moderasi agama dengan menyelenggarakan kegiatan pertemuan dialog anak-anak muda yang berasal dari berbagai daerah di Indonesia. Kegiatan tersebut berlangsung selama 5 sampai 7 hari. Setelah kegiatan selesai, lembaga tersebut juga melakukan follow up terhadap peserta yang mengikuti kegiatan tersebut.

Dalam situasi politik yang selalu hangat, muncul prasangka saling mencurigai satu sama lain, terutama dalam beragama, sehingga saling tuduh dan saling membenarkan pendapat masing-masing. Fenomena kecurigaan berdampak pada ketegangan dalam beragama dan memunculkan klaim kebenaran sendiri. Permasalahan keagamaan dan kebangsaan merupakan dua sisi yang menyebabkan disintegrasi bangsa yang diekskpresikan dengan cara 
kekerasan. Hal ini disebabkan egosentrisme beragama yang dilakukan oleh masing-masing penganut agama. Menghadapi situasi dan kondisi bangsa semacam ini, Buya Syafii yang memiliki kekayaan intelektual dan pengalaman cukup luas, merasa terpanggil untuk ikut serta menyuarakan moderasi agama di Indonesia, walaupun telah memasuki usia 85 tahun, namun tidak mengurangi semangatnya.

Ada beberapa penelitian terkait tentang Buya Syafii, diantaranya dapat ditemukan dalam beberapa tulisan berikut; pertama, penelitian yang dilakukan oleh Muhammad Wahid Nur Tualeka tahun 2018 yang berjudul Konsep Toleransi Beragama menurut Buya Syafii Maarif. Penelitian ini mengkaji makna toleransi dalam pandangan Ahmad Syafii Maarif dan sumbangsihnya (Tualeka, 2018, hal. 1). Kedua, penelitian yang berjudul Hubungan Islam dan Negara dalam Pandangan Ahmad Syafii Maarif yang ditulis oleh Leni Marlena tahun 2018 yang fokus mengkaji tentang hubungan Islam dan negara dalam pandangan Ahmad Syafii Maarif (Marlena, 2018, hal. 21). Ketiga, penelitan yang ditulis oleh Nuraini pada tahun 2019 dengan judul Humanisme Islam dalam Pemikiran Ahmad Syafii Maarif, penelitian ini mengkaji pemikiran humanisme Ahmad Syafii Maarif (Nuraini, 2019, hal. 126). Keempat, penelitan yang ditulis oleh Damanhuri tahun 2015 yang berjudul Islam, Keindonesiaan dan Kemanusiaan (Telaah Pemikiran Ahmad Syafii Maarif) dengan fokus penelitian mengenai kerangka berpikir Ahmad Syafii Maarif tentang keislaman, keindonesiaan dan kemanusiaan (Damanhuri, 2019, hal. 77). Dan kelima, penelitian yang berjudul Pemikiran Ahmad Syafii Maarif terhadap Kedudukan Perempuan dalam Politik yang ditulis Fatmawati dan Latifah Anwar tahun 2020, yang fokus meneliti tentang pemetaan pemikiran Ahmad Syafii Maarif terhadap kedudukan perempuan dalam politik menurut ajaran Islam (Fatmawati \& Anwar, 2020, hal. 191).

Artike ini menjelaskan pemikiran Buya Syafii dalam pengembangan moderasi Islam di Indonesia. Buya Syafii mempunyai gaya tersendiri dalam mengembangkan moderasi Islam dengan menekankan pada sikap dan tindakan semua agama pada moderat antar sesama agama agar tercipta Indonesia sebagai bangsa yang semakin harmonis. Artikel memaparkan beberapa rumusan pertanyaan, yaitu: bagaimana moderasi Islam dalam pandangan Ahmad Syafii Maarif? Bagaimana upaya-upaya Ahmad Syafii Maarif agar penganut agama menampilkan wajah moderat terhadap agama lain? Juga bagaimanakah kontribusi moderasi Islam Ahmad Syafii Maarif terhadap pluralitas agama di Indonesia. 


\section{Konsep Moderasi Agama}

Moderasi agama adalah lawan dari bentuk ekstremisme agama. Istilah moderasi berasal dari bahasa Latin, dari kata Moderare yang artinya mengurangi atau mengontrol. Kamus The American Heritage Dictionary of the English Language mendefinisikan moderate sebagai: not excessive or extreme (tidak berlebihan dalam hal tertentu). Kesimpulan awal dari makna etimologi ini bahwa mengandung makna obyektif dan tidak ekstrim, sehingga definisi akurat moderasi agama adalah nilai-nilai agama yang dibangun atas dasar pola pikir yang lurus dan pertengahan (Faiqah \& Pransiska, 2018, hal. 46).

Moderasi agama adalah sebuah pandangan atau sikap yang selalu berusaha mengambil posisi tengah dari dua sikap yang berseberangan dan berlebihan sehingga salah satu dari kedua sikap yang dimaksud tidak mendominasi dalam pikiran dan sikap seseorang. Dengan kata lain, seorang umat agama yang moderat adalah umat yang memberi setiap nilai atau aspek yang berseberangan bagian tertentu tidak lebih dari hak yang semestinya. Karena manusia-siapapun ia-tidak mampu melepaskan dirinya dari pengaruh dan bias, baik pengaruh tradisi, pikiran, keluarga, zaman, dan tempatnya.

Perlunya ditanamkan nilai-nilai moderasi pada setiap agama karena adanya potensi radikal pada setiap penganut, apapun agamanya. Radikalisme sebagai pemicu menispisnya suara-suara moderat yang semestinya disuarakan oleh setiap agama. Radikal sendiri berasal dari bahasa latin "radix" yang artinya akar. Dalam bahasa Inggris kata radikal dapat bermakna ekstrim, menyeluruh, fanatik, revolusioner, ultra dan fundamental (Sydney, 2000, hal. 691). Sedangkan "radikalisme" artinya doktrin atau praktik penganut paham radikal atau paham ekstrim (Nuh, 2009, hal. 36). Dalam Kamus Besar Bahasa Indonesia, radikalisme diartikan sebagai paham atau aliran yang menginginkan perubahan dengan cara keras atau drastis (Kebudayaan, 1989). Lebih jauh, dipaparkan bahwa radikalisme menurut Kamus Ilmiah Populer berasal dari kata "radikal" yang artinya besar-besaran dan menyeluruh, keras, kokoh, maju, dan tajam (dalam berfikir) (Partanto \& Barry, 1994, hal. 648).

Tindakan kekerasan, brutalitas, bahkan peperangan atas nama agama bukan barang baru dalam sejarah peradaban (kebiadaban) manusia. Pelaku tindakan ini merasa paling beriman di muka bumi. Karena menganggap diri sebagai makhluk agung di antara manusia, mereka mengangkat dirinya sebagai orang yang paling dekat dengan Tuhan. Karena itu, mereka berhak 
memonopoli kebenaran. Seakan-akan mereka telah menjadi wakil Tuhan yang sah untuk mengatur dunia ini berdasarkan tafsiran monolitik mereka terhadap teks suci. Perkara pihak lain akan mati, terancam, binasa, dan babak belur akibat perbuatan anarkis mereka, sama sekali tidak menjadi pertimbangan. Inilah jenis manusia yang punya hobi "membuat kebinasaan di muka bumi", tetapi merasa telah berbuat baik (Maarif, 2010, hal. 13).

Konsep radikalisme adalah paham yang menganut cara radikal. Dalam hal ini radikalisme merupakan suatu paham yang menginginkan perubahan yang radikal tanpa mengindahkan pemahaman dan perkembangan pemahaman yang berkembang disekitarnya (Pusat Pembinaan dan Pengembangan Bahasa, 2008, hal. 1248). Dengan demikian konsep yang dibawa radikalisme dapat dimaknai sebagai suatu sikap atau keadaan yang mendambakan perubahan terhadap tatanan yang sudah ada dengan jalan menghancurkannya secara totalitas dan menggantinya dengan sesuatu yang baru yang sama sekali berbeda. Biasanya cara yang digunakan bersifat revolusioner, artinya menjungkirbalikkan nilai-nilai yang ada secara drastis lewat kekerasan dan aksi-aksi yang ekstrim (Taher, 2002, hal. 176).

\section{Moderasi Islam dalam Dimensi Trilogi Islam}

Fenomena wasathiyah (moderat) mewarnai bidang aqidah, bidang akhlak-tasawuf dan bidang syariat (Al-Harafi dalam Yusuf, 2018, p. 207).

\section{Bidang Aqidah}

Beberapa contoh moderasi Islam dalam aspek aqidah dapat dilihat dalam beberapa hal, antara lain: Pertama, Ketuhanan antara atheisme dan politheisme. Islam ada di antara Atheisme yang mengingkari adanya Tuhan dan Politheisme yang memercayai adanya banyak Tuhan. Artinya, Islam tidak mengambil paham Atheisme dan tidak pula paham Poletheisme, melainkan paham Monotheisme, yakni paham yang memercayai Tuhan Yang Esa (AlQardlawi dalam Yusuf, 2018, p. 207). Kedua, alam antara kenyataan dan khayalan. Islam yang memiliki watak moderat menempatkan dirinya di antara pandangan yang tidak memercayai adanya wujud selain alam nyata dan pandangan bahwa alam ini hanyalah sebuah khayalan yang tidak memiliki hakikat wujud yang sebenarnya. Bagi Islam, alam ini merupakan sebuah hakikat yang tidak diragukan, namun di balik itu, ada hakikat lain yaitu Dzat yang menciptakan dan mengaturnya (Yusuf, 2018). 


\section{Bidang Syariat}

Moderasi Islam di bidang syari'ah tampak sekali terlihat sifat wasaathiyah dan keseimbangan yang menyangkut berbagai persoalan. Misalnya; antara ketuhanan dan kemanusiaan. Kaum muslimin seluruhnya sepakat bahwa al-Hakim hanyalah Allah SWT. Ini artinya, bahwa manusiabagaimanapun tinggi ilmunya dan status sosialnya - tidak memiliki hak tasyri (mensyariatkan hukum) dan tidak mempunyai otoritas tahlil dan tahrim. Sedang peran yang dimainkan para mujtahid bukanlah tasyri', melainkan upaya menggali hukum-hukum Allah yang belum tampak atau masih tersembunyi di bawah permukaan sehingga menjadi ketentuan yang ready for use (Al-Zuhailiy dalam Syuhadak \& Badrun, 2012). Dari sisi ini tampak terlihat sifat ilahiyah (ketuhanan) dari hukum Islam. Di sisi yang lain, hukum Islam bersifat insaniyah (kemanusiaan), karena bertujuan untuk memenuhi kepentingan dan mewujudkan kesejahteraan manusia, zhahir-bathin, dunia-akhirat.

\section{Bidang Akhlak-Tasawuf}

Moderasi dalam akhlak-tasawuf, seperti yang diketahui inti tasawuf adalah takhalliy dan tahalliy, yakni membersihkan diri dari seluruh sifat tercela dan berhias diri dengan sifat-sifat terpuji. Pada aspek akhlak-tasawuf, moderasi Islam dapat digambarkan dengan sikap tengah: antara syariat dan hakikat. Di dalam melihat suatu persoalan, tasawuf tidak hanya menggunakan kacamata syariat atau kacamata hakikat saja, akan tetapi menggunakan keduanya. Karena syariat tanpa hakikat adalah kepalsuan, dan hakikat tanpa syari at merupakan omong kosong dan cenderung permissif terhadap kejahatan dan kezhaliman. Pepatah mengatakan: "Syariat tanpa hakikat itu bohong, dan hakikat tanpa syariat adalah kosong."

\section{Metode}

Penelitian ini merupakan penelitian kualitatif dengan pendekatan studi tokoh, yaitu ketokohan Buya Syafii. Dalam hal ini, Buya Syafii diteliti pandangannya tentang moderasi Islam yang memiliki kontribusi terhadap pluralitas agama di Indonesia. Adapun metode yang digunakan yaitu deskriptif-analitik, di mana penulis mendeskripsikan, mengungkapkan dan menguraikan apa adanya secara mendalam dari pemikiran Buya Syafii agar penulis dapat memahami jalan pikirnya untuk kemudian dianalisa secara kritis. 
Metode penalaran deduktif digunakan sebagai usaha untuk menjabarkan secara deskriptif data-data yang berupa pemikiran Buya Syafii tentang moderasi Islam secara umum lalu membuat analisis, kemudian menarik kesimpulan yang bersifat khusus.

Adapun sumber dari penelitian ini yaitu buku-buku karangan Buya Syafii dan buku-buku lainnya, artikel-artikel, serta penelitian terdahulu yang membahas tentang pemikiran moderasi Buya Syafii. Dalam pengumpulan data, hal yang dilakukan adalah inventarisasi kepustakaan yang berhubungan langsung dengan tema permasalahan judul. Setelah terkumpul data-data yang dimaksud dari pemikiran tokoh, kemudian perhatian penelitian diarahkan pada dimensi moderasi Islam Buya Syafii. Jika dimensi moderasi Islam Buya Syafii dapat dipetakan, selanjutnya dilakukan upaya mengolah dimensi moderasi tersebut dan melakukan kesimpulan seperlunya.

\section{Moderasi Islam dalam Perspektif Ahmad Syafii Maarif}

Dalam rangka menciptakan suatu fondasi kesatuan umat di mana persaudaraan hakiki benar-benar menjadi kenyataan, Buya Syafii melihat ada dua hal yang harus ditempuh. Pertama, membersihkan kecenderungankecenderungan batin-intelektual kita yang selama ini mungkin didominasi oleh etik golongan, suku, dan ras dengan etik al-Quran yang dipahami secara utuh, jujur dan bertanggung jawab. Kedua, menumbuhkan kesediaan kita untuk menilai secara kritis seluruh warisan intelektual dan kultural Islam melalui kritik sejarah, dengan ruh al-Quran di otak belakang kita (Maarif, 1995a, hal. 45).

Moderasi agama yang disodorkan Buya Syafii memang berangkat dari pemahaman agama yang ia anut, yaitu Islam. Buya Syafii menegaskan, "Kalau aku mengatakan bahwa Islam pilihanku yang terbaik dan terakhir, hak sama harus pula diberikan secara penuh kepada siapa saja yang mempunyai keyakinan selain itu. Semuanya ini kulakukan berdasarkan pemahamanku terhadap ayat-ayat al-Quran dalam Surat al-Baqarah: 256, Surat Yunus: 99, dan masih ada beberapa ayat lagi."

Bagi Buya Syafii, planet Bumi ini bukan hanya untuk pemeluk Islam, tetapi untuk semua, apakah mereka beriman ataupun tidak. Semuanya punya hak yang sama untuk hidup dan memanfaatkan kekayaan bumi ini di atas dasar keadilan dan toleransi. Tak seorang pun punya hak monopoli atas bumi ini. Oleh sebab itu, umat Islam semestinya secara aktif mengembangkan budaya 
toleransi ini dengan syarat pihak lain pun berbuat serupa. Jika ada gerakan agama atau politik yang ingin mengusir pihak lain dari muka bumi ini, maka mereka adalah musuh peradaban dan kemanusiaan yang harus dilawan, apa pun agama dan kepercayaannya (Maarif, 2013, hal. 225).

Suatu agama (apa pun agama itu) yang menghargai fitrah manusia dan menempatkan pada posisi yang terhormat, memang mungkin dapat ditawarkan sebagai fondasi spritual yang solid bagi peradaban yang akan datang. Syaratnya adalah bahwa pemeluknya punya wawasan global, mencintai dan menghayati keadilan, membela yang lemah, meyakini bahwa umat manusia merupakan satu kesatuan. Dadanya lapang untuk menenggang perbedaan agama dan keyakinan, sekalipun harus tetap tegar dalam membela dan mempertahankan prinsip imannya (Maarif, 1995b, hal. 52).

Menurut Buya Syafii, masyarakat yang hendak dibangun haruslah: terbuka, demokratik, toleran, dan damai. Empat ciri utama ini menurut hemat Buya Syafii haruslah dijadikan acuan bagi semua gerakan pembaharuan moral dan pembaharuan masyarakat Islam di muka bumi ini. Islam amat mendambakan terwujudnya sebuah bangunan masyarakat yang berwajah ramah dan anggun. Dalam masyarakat ini perbedaan agama, ideologi, dan nilai-nilai budaya, tidak boleh dijadikan penghambat untuk tercapainya citacita di atas (Maarif, 1995a).

Ciri keterbukaan berangkat dari sifat al-Quran sebagai Kitab Suci yang terbuka. Ia terbuka untuk diterima atau untuk ditolak. Sudah tentu dengan argumen-argumen yang kuat. Yang menolak al-Quran tidak harus dikucilkan dari masyarakat. Islam menerima hakikat pluralisme agama dan budaya. Sikap yang harus dikembangkan bukan sikap "monopoli" kebenaran, tapi sikap saling menghargai dan menghormati. Keterbukaan adalah watak dari sebuah perbedaan yang percaya diri. Sikap terbuka inilah pada masa lampau mendorong umat Islam berkenalan secara bebas dengan warisan ruhani hellenisme, Persia dan India. Adapun pada saat umat Islam telah kehilangan rasa percaya diri, sifat keterbukaan ini menjadi semakin redup. Dunia lalu menjadi amat sempit (Maarif, 1995a). Buya Syafii melayangkan kritikan kepada umat Islam sendiri, penulis melihat sikap Buya Syafii ini tidak hanya menghadapkan telunjuk kepada umat lain, tetapi telunjuk itu juga dihadapkan pada dirinya. 


\begin{abstract}
"Kenyataan ini merupakan kesulitan tersendiri bagi umat Islam Indonesia karena begitu beragamnya hasil pemikiran keislaman yang lahir dalam sejarah kontemporer Indonesia. Mereka yang tamatan Barat sering dicurigai sebagai pengikut kaum orientalis yang digambarkan serba merusak Islam. Dialog terbuka dan mendalam tentang pemikiran Islam yang beragam belum terjadi di Indonesia secara mendalam dan tuntas" (Maarif, 2013).
\end{abstract}

Tanpa toleransi sosial, manusia tidak mungkin dapat hidup aman dan damai. Dalam masalah toleransi ini, Islam boleh berbangga diri, khususnya terhadap kelompok non-Muslim. Dalam kasus ini, Islam normatif dan Islam sejarah seakan-akan telah menyatu. Hanyalah pada peristiwa-peristiwa yang tidak punya dampak besar sajalah umat Islam boleh jadi kurang menghiraukan budaya toleransi ini. Buku-buku sejarah banyak melukiskan ketinggian budi umat Islam dalam masalah tenggang rasa ini. Tapi yang ironis justru terletak pada kenyataan betapa sukarnya kadang-kadang dikembangkan sifat toleransi internal di kalangan umat Islam sendiri, khususnya dalam politik (Maarif, 1995a).

Cintalah yang semestinya menjadi pilar utama bagi asas hubungan antarmanusia, antarbangsa, antarkebudayaan, antarsistem hidup yang berbeda. Pertimbangan rasional dan kepentingan melulu tampaknya sering benar membawa pada kebinasaan. Perang adalah satu bentuk ekstrem yang destruktif dari corak hubungan manusia yang terlepas dari panduan cinta. Perang adalah manisfetasi dari iklim hati yang membeku, kecuali perang untuk membela diri dan membela keadilan yang hakiki (Maarif, 1995b).

Tugas manusia bukan untuk saling menjarah, saling menghancurkan, saling berpongah dengan peradaban masing-masing. Tugasnya adalah li ta'arafu (untuk saling mengenal, saling menghargai, saling memberi dan menerima) dengan landasan toleransi budaya yang kokoh, kreatif, dan dinamis. Di luar bingkai itu, iklim kehidupan di muka bumi ini akan tetap terasa panas dan ganas (Maarif, 1995b). Doktrin tentang keesaaan Allah dan kesatuan umat manusia adalah doktrin sentral dalam al-Quran. Dari doktrin inilah kemudian mengalir prinsip-prinsip tentang keadilan, persamaan, persaudaraan, dan toleransi. Mental yang dibentuk al-Quran adalah mental yang merdeka, bukan mental orang seolah-olah merdeka. Dengan demikian, tipe manusia yang diinginkan al-Quran adalah mereka yang full human, bukan sub-human. Di tangan kelompok yang full human inilah al-Quran dapat banyak berbicara (Maarif, 1995b). 
Bagi Buya Syafii, tidak ada masalah yang terlalu sulit untuk dipecahkan sekiranya semua pihak memakai pikiran jernih, dada lapang, dan punya ilmu yang memadai. Di atas itu semua, kultur keikhlasan dalam beragama merupakan modal utama yang harus dimiliki oleh semua pihak. Dalam ungkapan lain, egoisme mazhab, golongan, dan latar belakang sejarah secara berangsur harus digantikan oleh semangat persaudaraan imani yang demikian tajam diperintahkan al-Quran. Melalui pendekatan semacam ini, bagi Buya Syafii tidak ada masalah keumatan yang tidak dapat diselesaikan. Sekali lagi, kata kuncinya adalah keikhlasan beragama. Beragama semata-mata karena mencari ridha Allah (Maarif, 2013).

Pada bagian ini dapat penulis simpulkan bahwa moderasi agama Buya Syafii yang penulis maksud adalah bagaimana Buya Syafii selaku tokoh agama sekaligus tokoh bangsa memberikan tafsir segar agar setiap penganut agama apa pun memahami agamanya masing-masing secara esensi atau substansi. Karena pada dasarnya apa pun agamanya tidak ada yang mengajarkan kekerasan.

\section{Upaya-upaya Ahmad Syafii Maarif dalam Mewujudkan Moderasi Islam}

\section{Pra Memimpin Muhammadiyah}

Sepulang "nyantri" dari Chicago dengan Fazlur Rahman, kegiatan Buya Syafii belum begitu concern mengurus kegiatan kemasyarakatan, apalagi kegiatan lintas agama. Pasalnya sewaktu pulang dari Chicago kesibukan Buya Syafii lebih aktif di dunia kampus untuk mengajar, terutama sejarah. Menurut hemat penulis, karena belum begitu punya peran di Pengurus Pusat Muhammadiyah, inilah salah satu alasan mengapa kegiatan dalam menjalankan proyek moderasi Islam Buya Syafii belum begitu tampak (Maarif, 2013, p. 234).

\section{Selama Memimpin Muhammadiyah}

Selama periode Buya Syafii memimpin Muhammadiyah, ada beberapa kegiatan sampingan yang dilakukannya. Buya Syafii mengungkapkan, walaupun tidak sempat aktif benar, namun pada akhir November 1999 ia dipilih sebagai salah seorang presiden internasional dari WCRP (World Confrence on Religions for Peace) dalam sidang yang ke-7 di Amman, Yordania. Posisi ini sebelumnya diduduki oleh Abdurrahman Wahid dari NU (Maarif, 2013). 
Sejak Buya Syafii muncul sebagai Ketua PP Muhammadiyah dan sesudahnya, Buya Syafii telah biasa berdialog dengan tokoh-tokoh seperti B.J. Habibie, M. Amien Rais, Abdurrahman Wahid, Nurcholish Madjid, Franz Magnis Suseno, Biku Pannyavaro, Pdt Weinata Sairin, Romo Benny, Gunawan Muhammad, Mustofa Bisri, Amin Abdullah, dan puluhan lainnya, termasuk dengan anak-anak muda dari berbagai latar belakang (Maarif, 2013).

Dari pergaulan Buya Syafii dapat dicermati bahwa ia mudah berkawan dengan siapa pun, tanpa melihat perbedaan agama, etnis, budaya, bahkan dengan ateis sekalipun Buya Syafii bisa berteman. Sikap terbuka yang ada pada sosok Buya Syafii inilah mengapa ia mudah diterima oleh banyak kalangan, terutama minoritas yang merasa dikucilkan oleh mayoritas.

Pandangan Buya Syafii terhadap Islam tidak hanya mengeritik saja, tetapi ia juga membela bila itu dibutuhkan. Misalnya pada kasus Ambon, pedas sekali kritik dilayangkan oleh Buya Syafii untuk membela Muslim Ambon yang ia muat diresonansinya. Dalam tulisannya tersebut, ia ikut turun gunung berbuat menyelesaikan konflik tersebut di lapangan. Penulis turunkan di sini ringkasannya:

"Dari informasi otentik terakhir yang kita terima, pada tingkat akar rumput, di Ambon khususnya, umat Islam pun sudah muak dengan kata damai, sebab selalu saja dikhianati. Kalau situasi psikologis sudah berada pada point of no return seperti itu, kita dapat membayangkan bahwa kematian bukan lagi sesuatu yang ditakuti, melainkan dihadang setiap saat.

Apakah begini cara mengurus bangsa ini, membiarkan berlakunya dendam sejarah tak berkesudahan dengan korban yang terus berjatuhan? Agama dan akal sehat jelas mengutuk semua cara semacam itu, kecuali agama yang dipakai sebagai alat dan kendaraan politik. Semua agama dapat saja disalahgunakan untuk tujuan-tujuan jahat seperti yang sedang kita saksikan di panggung sejarah dalam berbagai periode. Apa yang terjadi di Maluku adalah penyalahgunaan agama demi meraih tujuan duniawi yang rendah amoral.

Sampai hari ini, rakyat kita di kawasan itu berbunuh-bunuhan, sementara aparatur seperti membiarkan semuanya itu berlaku. Dengan kenyataan itu, jika umat Islam dipaksa untuk menyatakan jihad dalam menbela diri dan kehormatan agama mereka, apa yang salah? Lembaga yang biasanya sangat lantang bersuara, dalam kasus Maluku, mengapa lebih banyak bungkam?" (Maarif, 2010). 
Dalam kapasitas sebagai Ketua Pengurus Pusat Muhammadiyah, Buya Syafii bersama Ketua PWM (Pimpinan Wilayah Muhammadiyah) Maluku, dan seorang temannya dari Makassar, pada 11 Januari waktu itu menemui Kasum TNI Letnan Jenderal Suaidi Marasabessy di Markas Besar TNI Cilangkap. Mereka mohonkan agar penyerangan dan pembunuhan terhadap umat Islam di Maluku dihentikan segera (Maarif, 2010).

Perkawanan Buya Syafii dengan tokoh-tokoh lintas agama semakin meyakinkannya bahwa sikap-sikap yang diperlihatkannya itu dalam memimpin Muhammadiyah mendapat apresiasi yang tinggi dari mereka. Tidak saja mereka, tetapi berbagai kalangan birokrat, jenderal, menteri, mantan menteri, pengusaha, budayawan/seniman, dan banyak yang lain sangat menghargai sikap pernyataan Buya Syafii untuk konsumsi publik. Mungkin mereka melihat Buya Syafii sebagai seseorang yang tua tanpa agenda pribadi untuk sebuah jabatan penting. Dengan demikian, tak ada seorang pun yang akan rugi bila bersahabat dengan Buya Syafii. Ia mengatakan: "Rasanya yang kukatakan memang tidak dibuat-buat. Semuanya keluar dari hati tanpa agenda jangka pendek. Dengan kata lain, perasaanku dengan mudah ditangkap oleh kawan-kawan itu, mungkin karena ada gelombang yang sama" (Maarif, 2012, hal. 314).

Tokoh-tokoh agama besar telah sering berkumpul di berbagai belahan bumi dan Buya Syafii sering juga terlibat dalam upaya mencari titik temu untuk merumuskan sumbangan agama terhadap perdamaian, tetapi belum pernah efektif. Salah satu sebabnya menurut Buya Syafii adalah kenyataan bahwa masalah internal agama sendiri masih jauh dari suasana damai, sementara manusia sekuler modern telah muak terhadap sesuatu yang bernama iman. Abad kita sekarang sedang berada di antara jepitan sekularisme ateistis dengan harapan besar manusia untuk kembali mengenal Tuhan (Maarif, 2013). Dalam "Cebu Dialoque on Regional Interfaith Cooperation for Peace, Development and Human Dignity" (Dialog Sebu tentang Kerja Sama Lintas Agama untuk Perdamaian, Pembangunan, dan Martabat Manusia). Dalam sidang pleno terakhir, Buya Syafii bahkan mengusulkan agar diadakan pula dialog antar komunitas agama dan komunitas nonagama, bahkan dengan komunitas ateis. Ia mengatakan:

"Tokoh semuanya adalah penduduk sah dari planet bumi yang tunggal ini. Alasan saya adalah jika perdamaian dunia hendak diwujudkan, sekalipun susah sekali, maka dialog perlu dilakukan, dengan syarat masing-masing 
pihak bersedia untuk saling menghargai dalam posisi yang sama, bukan untuk saling menghancurkan" (Maarif, 2010).

Bagi Buya Syafii, mengubah diri dari seorang beriman menjadi ateis adalah masalah pilihan dan kemauan bebas seseorang. Ancaman hukum mati atas orang semacam ini tidak akan pernah efektif, jika ateisme itu sudah menjadi pilihan hidupnya (Maarif, 2018, hal. 102). Artinya soal pilihan dalam menganut agama tertentu kita tidak boleh memaksakan ke pihak lain, tentunya muara pernyataan Buya Syafii ini adalah: terciptanya masyarakat yang damai, rukun, dan toleransi.

Selain kegiatannya di forum lintas agama, Buya Syafii juga mempunyai hubungan baik dengan tokoh agama lain seperti Franz Magnis-Suseno asal Jerman. Menurut Buya Syafii, semangat Magnis dalam membela Indonesia sebagai tanah airnya bisa mnegalahkan kesetiaan penduduk asli yang Muslim. Hubungan persahabatan Buya Syafii dengan Magnis telah berjalan cukup lama, mereka sering terlibat bersama dalam berbagai forum seminar dan yang sebangsa itu (Maarif, 1996, hal. 854).

\section{Pasca Memimpin Muhammadiyah}

Interaksi Buya Syafii dengan tokoh-tokoh lintas agama, lintas kultural, lintas etnis, para jenderal, birokrat, dan pengusaha, muslim dan nonmuslim, sungguh sangat subur di hari-hari tuanya (Maarif, 2013). Orang bisa saja menemukan kearifan itu di mana saja asal dicari dengan sungguh-sungguh melalui hati dan otak yang terbuka semata-mata karena rindu kepada kebenaran. Mengurung diri dalam pasungan pemikiran sempit atau hanya mengenal satu alur aliran pasti akan memperlama orang berada dalam suasana kebuntuan intelektual yang pengap, bahkan bisa membawa orang hidup dalam dunia semu, tidak menyentuh realitas. Padahal, Islam menurut pandangan Buya Syafii haruslah senantiasa bersentuhan dengan realitas; bukan saja bersentuhan, tetapi malah wajib berupaya mengubah realitas yang pengap menjadi sesuatu yang asri, adil, dan penuh rahmat yang dapat diukur dengan parameter apa pun (Maarif, 2013).

Pasca kepemimpinan Buya Syafii dengan berbagai tokoh-tokoh agama lain, cukup terasa pemikiran dan sikap moderasinya di hari tua. Penulis rangkumkan beberapa anggapan tokoh-tokoh agama lain terhadap sikap moderat Buya Syafii. Dalam pergaulan lintas iman, seorang sahabat Buya Syafii, Dr. I. Suharyo, Uskup Agung Semarang, menulis: 
Melepaskan diri dari belenggu-belenggu sejarah bukanlah perkara mudah dan dapat dilaksanakan dalam waktu singkat. Yang jelas, haruslah dibangun sejarah baru yang tidak membelenggu, tetapi sebaliknya, sejarah yang membebaskan dan memberi harapan. Untuk itu dituntut mutlak peran para tokoh sejarah. Bapak Syafii adalah salah seorang tokoh terkemuka yang sudah lama memainkan peranan itu-dengan pemikiranpemikiran beliau yang cerdas, terbuka, inspiratif, dan langkah-langkah moral beliau yang berani-dan kita harapkan akan terus memerankannya (Ghazali \& Daulay, 2005, hal. 555).

Sikap yang mirip juga dapat ditemukan pada Biksu Pannyavaro dari candi Mendut. Dalam sebuah pembicaraan Buya Syafii dengan Biksu di Viharanya pada suatu hari saat Buya Syafii dan istrinya Nurkhalifah berkunjung ke sana, Pannyavaro mengatakan bahwa jumlah pengikut yang besar tidak penting. Kualitas komitmen mereka kepada kebaikan jauh lebih utama. Biksu ini telah menjadi sahabat Buya Syafii selama beberapa tahun. Mereka saling menghargai dalam perbedaan, tetapi kami bertemu dalam biduk moral untuk kebaikan semua makhluk. Bagi Buya Syafii persaudaraan tulus lintas iman terasa amat mengharukan. Ternyata kemanusiaan itu memang satu (Maarif, 2012).

Salah seorang sahabatnya lagi, Sudhamek, Ketua Umum Budhayana Indonesia, di akhir masa jabatan Buya Syafii di PP Muhammadiyah pernah juga mengantarkan cek sebesar Rp 75.000.000,00 untuk membantu pelaksaaan Muktamar Malang. Jadi, muslim dan nonmuslim telah menjadi sahabatsahabatnya yang akrab dan tulus. Sewaktu ia masih menjadi Wakil Ketua PP, suasana semacam ini belum tercipta. Rupanya orang kemudian melihat bahwa kiprahnya sebagai ketua sedikit atau banyak telah turut membawa kesejukan dalam masyarakat luas Indonesia (Maarif, 2013).

Selain tokoh-tokoh lintas agama, pujian yang serupa terhadap Buya Syafii juga datang dari kalangan intelektual seperti Noorhaidi Hasan dan Zuly Qodir. Berikut penulis muat pernyataan Hasan dan Zuly. Hasan mengatakan:

Buya Syafii adalah seorang intelektual Muslim Indonesia par excellence yang menekankan semangat moral Islam dalam bernegara. Lewat ijtihad politik garam-nya, Buya Syafii telah berhasil menepis kelompok 'khawarij gaya baru' yang bercita-cita ingin mendirikan 'Negara Tuhan' sembari membajak ayat-ayat Tuhan (Hasan, 2015).

Begitu juga dengan Zuly, ia bahkan melampaui Hasan dalam memuji sikap Buya Syafii dalam hubungan antaragama: 
Berdasarkan kajian atas perjalanan (ziarah iman) Buya Syafii Maarif dalam aktivitas perdamaian, membela Islam rahmatan lil alamin, Islam yang ramah, penolakan atas pembohongan publik oleh kekuasaan (negara) yang mengarah pada politik despotik karena penuh pencitraan dan kepalsuan, gerakan pemberantasan korupsi secara nasional melalui organisasi Muhammadiyah dan ormas Islam lain seperti NU agamaagama Abraham lainnya, serta penolakannya atas gerakan radikalisme, penggunaaan metode kekerasan dalam menyebarkan Islam, menolak terorisme dan kejahatan-kejahatan serta kejahatan kultural lainnya. sebenarnya dapat dikatakan Buya Syafii tengah mengembangkan tradisi Neo-Jihad untuk umat beriman di Indonesia dalam merespons masalahmasalah kebangsaan, keindonesiaan, dan keislaman (Qodir, 2015).

Pergaulannya dengan berbagai ragam manusia telah semakin menyadarkannya bahwa manusia itu sungguh banyak sekali dimensinya. Entah apa alasan dan daya pikatnya, hubungan mereka dengan Buya Syafii terasa begitu akrab, baik sebelum maupun sesudah Muktamar Jakarta (Maarif, 2013).

Usia yang telah merangkak jauh semakin menyadarkan Buya Syafii untuk lebih berhati-hati dalam menjaga hubungan dengan sesama, baik teman seagama maupun dengan teman lintas agama yang sampai sekarang tetap terjaga dengan baik, apalagi Muhammadiyah adalah gerakan dakwah, bukan gerakan politik yang tidak bebas dari budaya "menohok kawan seiring, menggunting dalam lipatan" (Maarif, 2013).

\section{Kontribusi Moderasi Islam Ahmad Syafii Maarif terhadap Pluralitas Agama di Indonesia}

Sekalipun Buya Syafii sendiri belum melahirkan sebuah teori yang utuh tentang moderasi agama, setidaknya ia telah merintis kerja ke arah itu dalam beberapa buku yang telah dihasilkannya. Beberapa orang telah menulis tentang beberapa aspek pemikirannya untuk skripsi, tesis, dan bahkan kabarnya juga disertasi. Nguyen Canh Toan dari Departemen Luar Negeri Vietnam yang belajar di Universitas Gadjah Madah telah menulis tesis tentang pandangan Buya mengenai pluralisme budaya dan agama selama Buya menjadi Ketua PP Muhammadiyah (1998-2005). Mungkin saja hasil pemikirannya ini baru berupa fragmen-fragmen, tetapi telah mulai menarik minat orang untuk mengkajinya (Maarif, 2013).

Selama empat tahun lebih di Chicago, perkisaran cara berpikir Buya Syafii ini sungguh terasa sekali. Bahwa Buya Syafii pernah dituduh sebagai antek kaum orientalis, baginya biarlah tuduhan itu diteriakkan terus. Sikap 
moral yang dibuktikan selama ini akan menjelaskan di mana sebenarnya posisinya dalam soal bernegara ini dengan segala pluralitas agama yang ada di dalamnya. Buya Syafii lebih mementingkan substansi yang memberi solusi terhadap masalah kemasyarakatan dan kemanusiaan, bukan merek luar dengan isi yang penuh borok politik.

Buya Syafii sudah lama kehilangan kepercayaan kepada kelompokkelompok radikal yang sesungguhnya sangat haus kekuasaan itu. Sebagian mereka menempuh cara-cara kekerasan. Kekerasan atas nama agama telah menjadi mata pencaharian. Alangkah kotornya cara-cara semacam ini (Maarif, 2013).

Barangkali saja usia Buya Syafii yang sudah tidak lagi muda ini tidak akan punya kesempatan lagi untuk menyaksikan kebangkitan peradaban Islam yang autentik, toleran, dan berkualitas tinggi. Akan tetapi, setidaknya ia dengan bekal "pesantren" Chicago tidak pernah tinggal diam dalam menyuarakan pemikiran-pemikiran terobosan sekalipun nilainya belum seberapa dikaitkan dengan harapan yang teramat besar untuk sebuah perubahan yang fundamental dengan al-Quran sebagai hakim yang tertinggi (Maarif, 2013).

Kontribusi pemikiran Buya Syafii tentang moderasi Islam tidak hanya diaktualisasikan dalam gerakan, tapi juga direkamnya dalam tulisan. Berikut penulis muat bagaimana pembelaan Buya Syafii terhadap Ahmadiyah yang dirampas hak kebebasannya beragama:

Saya akan membela sepenuhnya posisi Ahmadiyah jika mereka dizalimi, hak milik mereka dirampok, dan keluarga mereka diusir. Ini perbuatan biadab karena pengikut Ahmadiyah itu punya hak yang sama dengan warga Negara Indonesia yang lain menurut konstitusi Indonesia. Jika mereka dizalimi, aparat dan kita semua wajib melindungi mereka. Bahkan, seorang warga Negara Indonesia penganut ateisme, tetapi patuh kepada UUD, tidak ada hak kita untuk membinasakan mereka. Kita bisa bergaul dengan mereka dalam masalah-masalah keduniaan. Mereka juga punya hak hidup dengan ateismenya (Maarif, 2010).

Di sinilah pentingnya kita memahami secara jujur diktum al-Quran dalam al-Baqarah ayat 256, "Tidak ada paksaan dalam agama." Jika Tuhan tidak mau memaksa hambanya untuk memeluk atau tidak memeluk agama, mengapa manusia mau main paksa atas nama Tuhan? Sikap semacam inilah yang bikin kacau masyarakat. Oleh karena itu, al-Quran jangan dibawa-bawa untuk menindas orang lain. Kekerasan atas nama agama adalah pengkhianatan 
yang nyata terhadap hakikat agama itu sendiri. Pemahaman sektarian betapapun diramu dan dirumuskan dengan artikulasi yang tinggi tetap tidak bersikap adil terhadap Al-Quran (Maarif, 1995a).

Kritik Buya Syafii tidak hanya diutarakan kepada Islam garis keras, tetapi agama lain pun tak luput dari kritiknya. Dari beberapa pandangan Buya Syafii yang penulis muat di sini akan terlihat bahwa ia menginginkan supaya setiap penganut agama tertentu saling menghargai satu sama lain untuk menciptakan kehidupan yang rukun, damai, toleransi.

Sesungguhnya Buya Syafii adalah seorang tokoh yang selama bertahuntahun malang-melintang menjaga hubungan harmonis lintas agama di Indonesia. Ia menginginkan agar Indonesia yang plural jangan sampai berkeping-keping oleh ulah kaum fundamentalis: Islam, Kristen, atau siapa saja yang memakai kacamata kuda dalam memahami agama. Dalam resonansinya Buya Syafii menyebut Bush sebagai fundamentalis Kristen yang ingin menginjilkan dunia dengan cara-cara yang biadab, sebagaimana Kevin Phillips telah menelusuri sejarah panjang tentang masalah ini dalam karya terbarunya, American Theocray, sebuah buku terlaris menurut New York Times` (Maarif, 2010). Apa yang dikatakan Buya Syafii adalah sesuatu yang kasat mata yang tidak bisa dibantah, bahwa kekerasan dalam agama apa pun tidak bisa dibiarkan merajalela.

Selain pengaruh Fazlur Rahman dalam memberikan tafsir segar soal hubungan antar agama, Buya juga memuji Hamka ketika menafsir ayat alQuran tentang pentingnya merawat persaudaraan meskipun berbeda agama.

Sikap Hamka yang menolak bahwa ayat 62 al-Baqarah dan ayat 69 alMaidah telah dimansukhkan oleh ayat 85 surat Ali 'Imran adalah sebuah keberanian seorang mufassir yang rindu melihat dunia ini aman untuk didiami oleh siapa saja, mengaku beragama atau tidak, asal saling menghormati dan saling menjaga pendirian masing-masing. Sepengetahuan Saya tidak ada Kitab Suci di muka bumi ini yang dimiliki ayat toleransi seperti yang diajarkan al-Quran. Pemaksaan dalam agama adalah sikap yang anti al-Quran (Maarif, 2010).

Secara normatif, tidak ada satupun agama yang menganjurkan pemeluknya untuk melakukan tindak kekerasan, baik terhadap sesamanya yang berbeda pandangan (mazhab) maupun pada pengikut agama lain. Namun, secara faktual-historis, tidak jarang dijumpai tindak kekerasan yang dilakukan masyarakat agamis. Bahkan, ada kecenderungan bahwa kekerasan ini justru 
dilakukan oleh mereka yang bisa dikatakan mempunyai basis agama yang kuat dan melakukannya dengan atas nama agama (Putra, 2018, hal. 131).

Membanjirnya literatur dan kajian Islam pascaserangan sekelompok pemuda Arab pembajak pesawat-pesawat jet komersial Amerika Serikat atas gedung kembar pencakar langit WTC di New York dan Pentagon di Washington pada 11 Sepetember 2001 agaknya belum berhasil menjernihkan pemahaman banyak kalangan tentang aksi-aksi kekerasan atas nama agama, atau lazim disebut radikalisme agama (Hasan, 2008, hal. vii). Untuk menegakkan masyarakat pluralistik yang harmonis, maka Piagam Madinah telah mewarisikan kepada kita prinsip-prinsip yang tahan banting sejarah. Oleh kerena itu, agar mempunyai landasan moral-religius yang kokoh dan anggun, Piagam Madinah dapat diambil sebagai pedoman bermasyarakat dan bernegara oleh siapa pun.

Khusus untuk Indonesia yang terdiri atas ribuan pulau, demi melestarikan persatuan dan kesatuan bangsa, Piagam Madinah dapat pula dijadikan acuan. Sebuah bangsa dapat mengalami kehancuran bila toleransi sosial, agama, dan budaya tidak mantap (Maarif, 1996). Karya-karya yang telah dihasilkan Buya Syafii dalam bentuk buku, artikel, makalah, dan sejenis dengan itu telah meransang akademisi meneliti pemikirannya yang moderat dalam bentuk skripsi, tesis, bahkan disertasi. Artinya, pemikiran moderasi yang diusungkan oleh Buya Syafii sudah mulai menampakkan hasil. Sementara secara aplikatif pemikiran moderasi itu sudah dilakukan seperti kasus Ambon, aktif di forum lintas agama (nasional dan internasional), bahkan memprakarsai berdirinya Maarif Institute sebagai lembaga yang mempunyai perhatian terhadap masalah kemanusiaan. Singkatnya, pemikiran moderasi Islam Buya Syafii tidak hanya dalam bentuk pemikiran, tetapi juga dicontohkan dalam bentuk aksi-kata dan laku sejalan.

\section{Simpulan}

Berdasarkan uraian pembahasan di atas, jawaban dari pertannyaan penelitian ini, yaitu: Pertama, moderasi Islam dalam pandangan Ahmad Syafii Maarif adalah bagaimana memberikan tafsir ulang teks agama (Islam) supaya agama disikapi dan dipahami oleh penganutnya, esensi dan substansi agama itu sendiri. Tujuannya agar bermuara pada: semakin sehatnya sikap toleransi di tengah-tengah umat beragama. 
Kedua, upaya-upaya yang dilakukan Ahmad Syafii Maarif agar setiap penganut agama menampilkan wajah moderat terhadap agama lain adalah aktif di berbagai forum lintas iman, dan menyuarakan pesan moderasi lewat tulisan-tulisannya yang terdapat di berbagai buku, artikel, forum dan media massa. Selain itu, ia juga memprakarsai berdirinya Maarif Institute sebagai lembaga yang bergerak di bidang kemanusiaan dan kebudayaan.

Ketiga, kontribusi moderasi Islam Ahmad Syafii Maarif terhadap pluralitas agama di Indonesia adalah telah memantik semangat anak-anak muda menyelenggarakan dialog di berbagai forum lintas agama. Selain itu, telah mengajarkan kepada umat Islam agar bersedia berteman dengan siapa saja dalam memperjuangkan biduk moral mencapai kerukunan umat beragama. Terakhir, secara aplikatif moderasi Islam Buya Syafii selain mendirikan Maarif Institute yang concern terhadap isu-isu kebudayaan dan kemanusiaan, ia juga ikut meredam konflik intern dan antar umat beragama, khususnya di Indonesia.

\section{Referensi}

Damanhuri. (2019). Islam, Keindonesiaan, dan Kemanusiaan (Telaah Pemikiran Ahmad Syafii Maarif). Al-Banjari: Jurnal Ilmiah Ilmu-Ilmu Keislaman, 53(9), 7684 .

Faiqah, N., \& Pransiska, T. (2018). Radikalisme Islam vs Moderasi Islam: Upaya Membangun Wajah Islam Indonesia yang Damai. Al-Fikra : Jurnal Ilmiah Keislaman, 17(1), 33-60.

Fatmawati, \& Anwar, L. (2020). Pemikiran Ahmad Syafii Maarif terhadap Kedudukan Perempuan dalam Politik. Al-Muaddib: Jurnal Ilmu-Ilmu Sosial dan Keislaman, 5(2), 191-197.

Ghazali, A. R., \& Daulay, S. P. (2005). Cermin untuk Semua: Refeleksi 70 Tahun Ahmad Syafii Maarif (Daulay, Sa). Maarif Institute.

Hanafi, R. (2018). Datangi Gereja Lidwina yang Diserang, Buya Syafii: Saya Kecewa Berat. detiknews.

Hasan, N. (2008). Laskar Jihad: Islam, Militansi, dan Pencarian Identitas di Indonesia Pasca-Orde Baru. LP3ES.

Hasan, N. (2015). Buya Syafii: Penjaga Pluralisme, Pengawal Keutuhan Bangsa. In N. Burhani (Ed.), Muazin Bangsa dari Makkah Darat: Biografi Intelektual Ahmad Syafii Maarif (hal. 432). Maarif Institute.

Ikhwan, H. (2018). Disampaikan Pada Seminar. "Pemuda untuk Indonesia Damai".

Kardi, D. D. (2016). Datang ke Gereja St Lidwina, Syafii Maarif Kutuk Penyerangan. CNN Indonesia. 
Kebudayaan, D. P. dan. (1989). Kamus Besar Bahasa Indonesia. Balai Pustaka.

Maarif, A. S. (1995a). Mambumikan Islam. Pustaka Pelajar.

Maarif, A. S. (1995b). Peta Bumi Intelektualisme Islam di Indonesia. Mizan.

Maarif, A. S. (1996). Islam dan Politik Teori Belah Bambu. Gema Insani Press.

Maarif, A. S. (2010). Al-Qur'an dan Realitas Umat. Republika.

Maarif, A. S. (2012). Politik Identitas dan Masa Depan Pluralisme Kita. Democracy.

Maarif, A. S. (2013). Memoar Seorang Anak Kampung. Ombak.

Maarif, A. S. (2018). Krisis Arab dan Masa Depan Dunia Islam. Bentang Pustaka.

Marlena, L. (2018). Hubungan Islam dan Negara dalam Pandangan Ahmad Syafii Maarif. Manthiq, 3(2), 21-40.

Nuh, N. M. (2009). Faktor-Faktor Penyebab Munculnya Faham/Gerakan Islam Radikal di Indonesia. Harmoni: Jurnal Multikultural \& Multireligius, 8(2), 35-47.

Nuraini. (2019). Humanisme Islam dalam Pemikiran Ahmad Syafi'i Ma'arif. Edukasia Multikultura, 1(1), 126-136.

Paath, C. K. (2018). Terorisme dan Radikalisme Marak, Mendagri: Tentukan Siapa Kawan dan Lawan. Beritasatu.com.

Partanto, P. A., \& Barry, M. D. Al. (1994). Kamus Ilmiah Populer. Arkola.

Pusat Pembinaan dan Pengembangan Bahasa. (2008). Kamus Besar Indonesia (Cetakan VI). Pusat Bahasa.

Putra, R. (2018). Pemikiran Farid Esack Tentang Hemeneutika Pembebasan. In A. Mustaqiem (Ed.), Studi Al-Qur'an dan Hadits: Perspektif Teks dan Konteks (hal. 250). FA Press bekerjasama dengan Program Studi Magister Aqidah dan Filsafat Islam Fakultas Ushuluddin UIN Sunan Kalijaga.

Qodir, Z. (2015). Ziarah Iman Cendekiawan-Negarawan: Neo-Jihad Antar-Iman dan Perdamaian. In N. Burhani (Ed.), Muazin Bangsa dari Makkah Darat: Biografi Intelektual Ahmad Syafii Maarif (hal. 432). Maarif Institute.

Sydney, H. A. (2000). Oxford Advanced Learner's Dictionary of Current English. Oxford University Press.

Syuhadak, F., \& Badrun. (2012). Pemikiran Wahbah Al-Zuhaily Tentang Ahkam AlUsrah. De Jure: Jurnal Syariah dan Hukum, 4(2), 160-170. https://doi.org/10.18860/j-fsh.v4i2.2985

Taher, T. (2002). Menyegarkan Akidah Tauhid Insani: Mati di Era Klenik (Cetakan I). Gema Insani Press.

Tualeka, M. W. N. (2018). Konsep Toleransi Beragama Menurut Buya Syafi'i Ma'arif. Al-Hikmah: Jurnal Studi Agama-Agama, 4(1), 1-18.

Yusuf, A. (2018). Moderasi Islam dalam Dimensi Trilogi Islam (Akidah, Syariah, Dan Tasawuf). Al-Murabbi: Jurnal Pendidikan Agama Islam, 3(2), 203-216. 
This page intentionally left blank 